\title{
Predicting the Suitability of Biogas Optimization from the Co- digestion of Plantain Peels and Poultry Waste Using Scheffe's Second Degree Polynomials
}

\author{
AniekanUdeme $^{\mathrm{a}}$, Samuel Assam ${ }^{\mathrm{b}}$, NnamnsoNnana ${ }^{\mathrm{c}}$, UbongUkpekpe ${ }^{\mathrm{d}}$ \\ Department of Civil Engineering, University of Uyo, Nigeria
}

\begin{abstract}
The optimization of biogas from poultry waste and plantain peels for biogas production was embarked on in this research work. The aim of this research is to determine the sustainability of poultry waste and plantain peels for biogas production. For the production, five batch digesters labeled $A$ to $E$ were designed and operated at room temperature for 35 days to study the biogas yield. Digester E was observed to commence production within 24 hours after loading while digester $A, C$, and D commences production after 96 hours and 24 hours respectively, while digester $B$ did not yield any gas. The cumulative yield of $A, C, D$ and $E$ were observed to be $184.9 \mathrm{ml}, 129 \mathrm{ml}, 287.41 \mathrm{ml}$ and $336.1 \mathrm{ml}$ respectively while digester B produce Oml.
\end{abstract}

Keywords: Anaerobic Process, Digestion, Biogas, Water, Optimization,Plantain Peel's, Poultry Waste, Retention Time, Digester and Scheffe'sSecond Degree Polynomials.

\section{Introduction}

Anaerobic digestion is the breakdown of organic material by a microbial population that lives in an oxygen free environment. Anaerobic literally means "without oxygen". When organic matter is decomposed in an anaerobic environment the bacteria produce a mixture of methane and carbon dioxide gas and other inert gases like hydrogen sulfide and ammonia. Anaerobic digestion treats waste by converting putrid organic materials to carbon dioxide and methane gas. This gas is referred to as biogas. The biogas can be used to produce both electrical power and heat. The conversion of solids to biogas results in a much smaller quantity of solids that can be used as soil conditioner in crop improvement. During the anaerobic treatment process, organic nitrogen compounds are converted to ammonia, sulfur compounds are converted to hydrogen sulfide, phosphorus to orthophosphates, and calcium, magnesium, and sodium are converted to a variety of salts. Through proper operation, the inorganic constituents can be converted to a variety of beneficial products: The end products of anaerobic digestion are natural gas (methane) for energy production, heat produced) from energy production, nutrient rich organic slurry, and other marketable inorganic products. Anaerobic digestion has been used for over 100 years to stabilize municipal sewage and a wide variety of industrial wastes. Most municipal waste water treatment plant use anaerobic digestion to convert waste solids to gas. The anaerobic process removes a vast majority of the odorous compounds (Lusk et al., 1995). [t also significantly reduces pathogens present in the slurry. Over the years, anaerobic digestion processes have been developed and applied to a wide array of industrial and agricultural wasted (Speece, 1996). It is the preferred waste treatment process, since it produces rather than consumes energy and can be carried out in a relatively small, enclosed tank or digester. The product of anaerobic digestion has value and can be sold to offset treatment cost. Biogas is normally produced by using the excreta of animals as the source material. In most of the countries where biogas is produced, the excreta of cattle and other farm animals are used. Under normal circumstances the microbial content of the biogas is maintained by the addition of $2 \%$ of the expended slurry of fresh dung. At times, waste of kitchens and excrement of human bodies is used in these processes. The ideal temperature for producing/biogas is within 29 to 32 degree Celsius. If the temperature is lower than that then production of biogas may go down as well. This is precisely the reason as to why thermal insulation is necessary to produce biogas.

Biogas is a non-conventional 'energy, which is actually a mixture of methane (CI-J4), carbon dioxide $\left(\mathrm{CO}_{2}\right)$ and depending on the feedstock or garbage used, traces of gases such as nitrogen, ammonia $\left.(\mathrm{NH}]\right)$, sulphur dioxide $\left(\mathrm{SO}_{2}\right)$ hydrogen sulphate $\left(\mathrm{H}_{2} \mathrm{~S}\right)$ and hydrogen. Biogas is produced

- The hornoacctogenic bacteria which can convert very wide spectrum or multi or monocarbon compounds to acetic acids.

- The mcthanogenic bacteria which convert $\mathrm{H} 2 / \mathrm{CO}_{2}$, rnonocarbon compounds (i.e. methanol, $\mathrm{CO}$, Methylamine) and acetate into methane or can form methane [rom decarboxylation of acetate.

These transformations and experiments were devised to help prove or disprove the multiple-organism theory. 


\section{Biogas as a Source of Energy}

Hundreds of millions of cubic feet of methane some-times called swamp or biogas are generated every year by the decomposition of organic materials. It's a near-twin of the natural gas that big utility eompanies pump out of the ground and which so many or use for heating our homes and for cooking. Instead of been harnessed like natural gas however, methane has

traditionally been considered as merely a dangerous nuisance that should be gotten rid of as fast as possible. Only recently have a few thoughtful men begun to regard methane as a potentially revolutionary source of controllable energy. In China, more than five million digesters now supply gas [or cooking lightning and powering agricultural equipment "each digester is an air-light chamber in which the fermentation of a mixture of animal dung, human excrement and crop residue such as straw yields a clean-burning gas that is onehalf to three-fourth methane' reports scientific American magazine. A standard digester yields as much as two cubic meters (7CU-ft.)

\section{Benefits of Biogas Production}

Processing organic waste anaerobically to create biogas is a sustainable.

Renewable waste to energy solution. The process offers numerous advantages over conventional technologies and if waste materials are used in the process, it can reduce greenhouse gas emission in four ways: - Preventing the uncontrolled emission of $\mathrm{CH}_{4}$ from landfills.

- The biogas fertilizer produced can displace mineral fertilizer. Nutrients are conserved with more than $90 \%$ nutrients entering anaerobic digesters conserved through the digestion process. By conserving nitrogen during digestion; the nitrogen potassium ratio of the treated manure is more favorable for plant growth.

- Reduce the transport or waste

- Renewable electricity and heat can be produced reducing greenhouse gas emissions. Since anaerobic digestion operates in a closed system, substantial reductions in greenhouse gas emissions are achieved. Other benefits of the process are odour-levels are greatly reduced during manure processing creating a relative lice odour-free product (closed vessel processing confined odourous compounds which are converted to other chemicals). Improve in slurry characteristics such as fluidity, crop compatibility, homogeneity and reduction of weed germs. Finally, anaerobic digestion greatly reduces pathogen levels.

\section{Steps for Biogas Production}

Digestion refers to various reactions and interactions that take place among the methanogens, nonmethanogens and substrates fed into the digester as slurry. The material to be processed can be shredded to increase the surface area available to microbes in the digesters and hence increase the speed of digestion. The anaerobic digestion process takes place in an air tight container, known as a digester.

The first stage of anaerobic digestion is a chemical reaction called:

- Hydrolysis, where complex organic molecules are broken into simple sugars amino acids, and fatty acids with the addition of hydroxyl groups. This is followed by three biological processes.

- Acidogenesis: further breakdown by acidogenic bacteria into simpler molecules, hydrogen sui fide as by products.

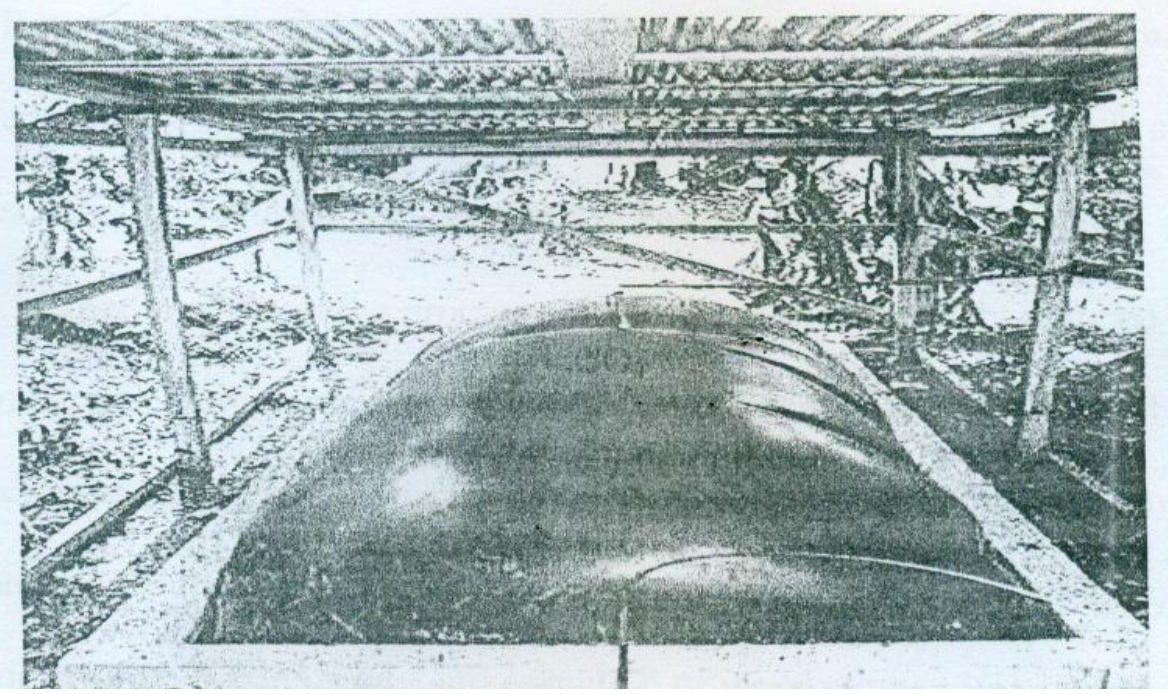

Fig. 1 A Bio Digester 


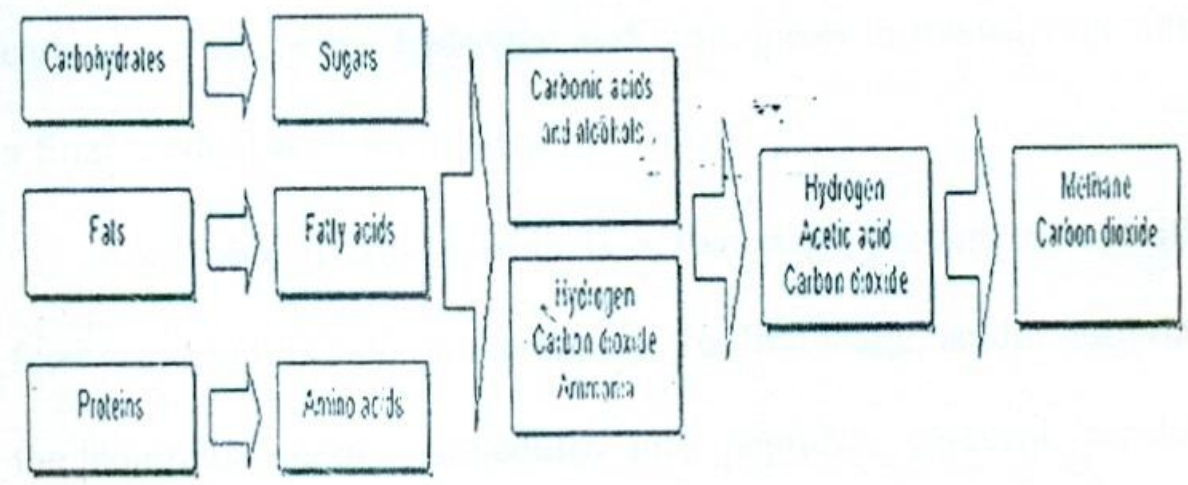

Fig.2 the Four Stages of Anaerobic Processes

The $\mathrm{pH}$ level should be kept between 5.5 to 8.5 and the temperature between $30-60^{\circ} \mathrm{C}$ in order to maximize digestion rate.

$$
\begin{aligned}
& \mathrm{CH}_{3} \mathrm{COOH} \Rightarrow \quad \mathrm{CH}_{4}+\mathrm{CO}_{2} \\
& 2 \mathrm{CH}_{3} \mathrm{CH}_{2} \mathrm{OH}+\mathrm{CO}_{2} \Rightarrow \quad \mathrm{CH}_{4}+2 \mathrm{CH}_{3} \mathrm{COOH} \\
& \mathrm{CO}_{2}+4 \mathrm{H}_{2} \Rightarrow \quad \mathrm{CH}_{4}+2 \mathrm{H}_{2} \mathrm{O}
\end{aligned}
$$

The above equations show that many by - products and intermediate products are produced in the process of digestion in an anaerobic condition before methane is produced.

\section{Nutrients}

\section{Factor Affecting the Production of Biogas}

Anaerobic decomposition of organic process will produce methane, carbon dioxide, some hydrogen and other gases in traces, very little heat and a final product with high nitrogen content.

Anaerobic decomposition is a two-stage process as specific bacteria feed on certain organic materials.' In the first stage, acidic bacteria dismantle the complex organic molecules into peptides, glycerol, alcohol and the simple sugars. When these compounds have been produced in sufficient quantities, a second type of bacteria starts to convert this simpler compound into methane. These methane producing bacteria are particularly influenced by the ambient conditions which can slow or halt the process completely if they do not lie within fairly narrow band.

\section{Acidity}

Anaerobic digestion will occur best within a $\mathrm{pH}$ range of 6.8 - 8.0. More acidity or basic mixtures will ferment at a lower speed. The introduction of raw material will often lower the $\mathrm{pH}$ (Making the mixture more acidic). Digestion will stop or slow dramatically until the bacteria have absorbed the acids. A high $\mathrm{pH}$ will encourage the production of acidic carbon

\section{Carbon-Nitrogen Ratio}

The bacteria responsible for the anaerobic process requires both elements, as do all living organisms but they consume carbon roughly 30 times faster than nitrogen. Assuming all other conditions are favourable for biogas production, a carbon-nitrogen ratio of about 25-1 is ideal for the raw material fed into a biogas digester. A higher ratio will leave carbon still available after the nitrogen has been consumed, starving some of the bacteria of this element. These will in turn die, returning nitrogen to the mixture, but showing the process. Too much nitrogen will cause this to be left over at the end of digestion (which stops when the carbon has been consumed) and reduce the quality of the fertilizer produced by the biogas plant. The correct ratio of carbon to nitrogen will prevent loss of either fertilizer quality or methane content.

\section{Temperature}

The anaerobic bacteria consortia function under three temperature ranges. Psychrophilic temperatures of less than 68 degrees Fahrenheit produce the least amount of bacterial action. Mesophilic digestion occurs between 68 degrees and 105 degrees Fahrenheit. Thermophilic digestion occurs between 110 degrees Fahrenheit and 160 degrees Fahrenheit. The optimum mesophilic temperature is between 95 and 98 degrees Fahrenheit. The optimum thermophilic temperature is between 140 and 145 degrees Fahrenheit. The rate of bacterial growth and waste degradation is faster under thermophilic conditions. On the other hand, thermophilic digestion 
produces an odorous effluent when compared to mesophilic digestion. Thermophilic digestion substantially increases the heat energy required for the process. In most cases, sufficient heat is not available to operate in the thermophilic range. Seasonal and diurnal temperature fluctuations significantly affect anaerobic digestion and the quantities of gas produced. Bacterial storage and operational controls must be incorporated in the process design to maintain process stability under a variety of temperature conditions.

Anaerobic breakdown of waste occurs at temperature lying between $\mathrm{O}^{\circ} \mathrm{C}$ and $69^{\circ} \mathrm{C}$, but the action of the digesting bacteria will decrease sharply between $16^{\circ} \mathrm{e}$. Production of gas is most rapid between $20^{\circ} \mathrm{c}$ and $41^{\circ} \mathrm{c}$ or between $49^{\circ} \mathrm{e}$ and $60^{\circ} \mathrm{c}$. This is due to the fact that two different bacteria are much more sensitive to ambient influences. A temperature between $320 \mathrm{e}$ and $350 \mathrm{e}$ has proven most efficient for stable and continuous production of methane. Biogas produced outside this range will have higher percentage of carbondioxide and other gases within the range.

\section{Percentage of Solids}

Anaerobic digestion of organics will proceed best if the input material consists of roughly $8 \%$ solids. In the case of fresh cow manure, this is the equivalent of dilution with roughly an equal quantity of water

\section{Retention Time}

This is the average period that a given quantity of input remains in the digester to be acted upon by the methanogens. In the digesting plant, theretention time is calculated by dividing the total volume of the digester by the volume of inputs added daily. The climatic condition of the environment has an effect on the retention time. At night, a longer retention time is needed so that the pathogens present in" humanfaeces are destroyed. The retention time is also dependent on the temperature of up to 3Soe, the higher the temperature, the lower the retention time.

\section{Toxicity}

Mineral Ions, heavy metals and detergents are some of the toxic minerals that inhibit the normal growth of pathogens in the digester. Small quantity of mineral ions (e.g sodium, potassium, calcium, magnesium ammonium and sulphur) also stimulated the growth of bacteria, while very heavy concentration of these ions will have toxic effect. For example, the presence of methane from 50 to $200 \mathrm{mg} / \mathrm{l}$ stimulated the growth of microbes, where as its concentration above $1,500 \mathrm{mg} /$ produces toxicity. Similarly, heavy metals such as copper, nicked, chromium, zinc, lead etc in small quantities are essential for the growth of bacteria but their higher concentration has toxic effects. Likewise, detergents including soap, antibiotics, organic solvents etc inhibit the activities of methane producing bacteria and addition of these substances in the digestion should be avoided.

Although there is a long list of substances that produce toxicity on bacteria growth, the inhibiting levels of some of the major ones are given in table 2.1 .

Table 2.1 Toxic Level of Various Inhibitors

\begin{tabular}{|c|c|}
\hline Inhibitors & Inhibiting concentration \\
\hline Sulphate $\left(\mathrm{SO}_{4}\right)$ & $5,000 \mathrm{pmm}$ \\
\hline $\begin{array}{l}\text { Sodium chloride or common salt } \\
\left(N_{a c 1}\right)\end{array}$ & 40,000ppm \\
\hline Nitrate (calculated as $\mathrm{N}$ ) & $0.05 \mathrm{mg} / \mathrm{ml}$ \\
\hline Copper $(\mathrm{cu}++)$ & $100 \mathrm{mg} / 1$ \\
\hline Chromium $(\mathrm{Cr}+++)$ & $200 \mathrm{mg} / 1$ \\
\hline Nickel $(\mathrm{Ni}+++)$ & $200-500 \mathrm{mg} / 1$ \\
\hline Sodium $(\mathrm{Na}+)$ & $3,500-4,500 \mathrm{mg} / 1$ \\
\hline Potassium $(k+)$ & $2,500-4-500 \mathrm{mg} / 1$ \\
\hline Calcium $\left(\mathrm{Ca}^{++}+\right)$ & $2,500-4,500 \mathrm{mg} / 1$ \\
\hline Magnesium (mg+ & $1,000-1,500 \mathrm{mg} / 1$ \\
\hline Manganese $(\mathrm{Mn}++)$ & Above $1,500 \mathrm{mg} / 1$ \\
\hline
\end{tabular}


Predicting the Suitability of Biogas Optimization from the Co-digestion of Plantain Peels and ..

Tab.2.2: General Features of Biogas (Deublein, 2008)

\begin{tabular}{|l|l|}
\hline Energy content & $6.0-6.5 \mathrm{kwh} / \mathrm{m}^{3}$ \\
\hline Fuel equivalent & $0.60-0.651 \mathrm{oil} / \mathrm{m}^{3}$ biogas \\
\hline Explosion limits & $6-12 \%$ biogas in air \\
\hline Theorition temperature & $650-750^{\circ} \mathrm{C}$ \\
\hline Critical pressure & $5.7 \mathrm{~m}^{3} \mathrm{air} / \mathrm{m}^{3}$ burning gas \\
\hline Critical temperature & $75-89 \mathrm{bar}$ \\
\hline Normal density & $-82.5^{\circ} \mathrm{C}$ \\
\hline Molar mass & $1.2 \mathrm{~kg} / \mathrm{m}^{3}$ \\
\hline Smell & $16.043 \mathrm{~g} / \mathrm{mol}^{2}$ \\
\hline
\end{tabular}

Source: The biogas technology in Deublein Germany, 2008)

\section{Sample Collection}

\section{Methodology}

The poultry waste was collected from a poultry farm located at Alakaiah community in Rivers State while the plantain peels were gotten from. Sonaz Restaurant, in Aluu Community of Rivers State. The poultry waste and the plantain peels were allowed to dry for twelve and twenty- one days respectively after which the poultry waste and the plantain peel were crushed mechanically using a plastic mortar and pestle to ensure homogeneity and to get a better surface area.

\section{Materials Collected}

The materials collected include the following:

i. 12 Buckner flasks ( 5 one liter and five $250 \mathrm{ml}$ sizes)

ii. Five conical flask $(100 \mathrm{ml})$

iii. 2 measuring cylinders $(0.2-10 \mathrm{ml}$ and $10-, 100 \mathrm{ml})$

iv. 10 corks

v. Glass connecting pipes

vi. Mortar and pestle

vii. Connecting hose

viii. Thermometer

ix. IX. Sieve

X. X. Weighing Balance

xi. XI. Dust proctor cotton

xii. XII. Hand Gloves

xiii. The materials were washed properly with detergent, rinsed and allowed to

xiv. dry by standing overnight in the laboratory. The chemical used include

xv. concentrated nitric acid $\left(\mathrm{HNO}_{3}\right)$ and sodium chloride $(\mathrm{NaCl})$. Tap water was

xvi. used for all dilution.

xvii.

\section{Choice of Design}

\section{Design and Analysis of the Experiment}

The design available in the study of biogas production from waste includeseither varying the retention time, keeping the total concentration constant, or varying the total solid concentration and keeping the retention time constant. Low solid anaerobic digestion process is a biological process in which organic waste are fermented at solid concentration equal to or less than $4 \%$ to $8 \%$. It involves the addition of considerable amount of waste to bring solid content to the required range of $4-8 \%$. 
Predicting the Suitability of Biogas Optimization from the Co-digestion of Plantain Peels and ..

\section{Preparation of Digester}

A set of five Buckner flasks was used as digesters each containing varying ratio of poultry waste and plantain peels at solid concentration equal to $5.26 \%$ The digesters were labeled A, B, C, D, and E, respectively. The composition by weight of poultry waste and plantain peels is shown below.

Results of Total Solids Determined Results of the total solid determination of the digester's content before and after experiment presented in Table 3.1

\begin{tabular}{|l|l|l|l|l|l|}
\hline DIGESTER & $\begin{array}{l}\text { Plantain } \\
\text { peels }(\mathrm{g})\end{array}$ & $\begin{array}{l}\text { Poultry } \\
\text { waste }(\mathrm{g})\end{array}$ & $\begin{array}{l}\text { Total } \\
\text { solids } \\
(\mathrm{g})\end{array}$ & $\begin{array}{c}\text { Total solid } \\
(\%)\end{array}$ & $\begin{array}{c}\text { Total solid } \\
(\mathrm{g})\end{array}$ \\
\hline A & 10.52 & 0 & 10.52 & 4.038 & 7.64 \\
\hline B & 2.63 & 7.89 & 10.52 & 4.038 & 7.80 \\
\hline C & 5.26 & 5.26 & 10.52 & 4.038 & 6.76 \\
\hline D & 7.89 & 2.63 & 10.52 & 4.038 & 8.98 \\
\hline E & 0 & 10.52 & 10.52 & 4.0 .38 & 7.16 \\
\hline
\end{tabular}

Table 3.1 Total solids of Digester's content before and after experiment

The digesters was allowed to run for 35 days and was agitated once daily between the hours of 10am to 12am. The daily reading is as shown plotted in Fig. 4

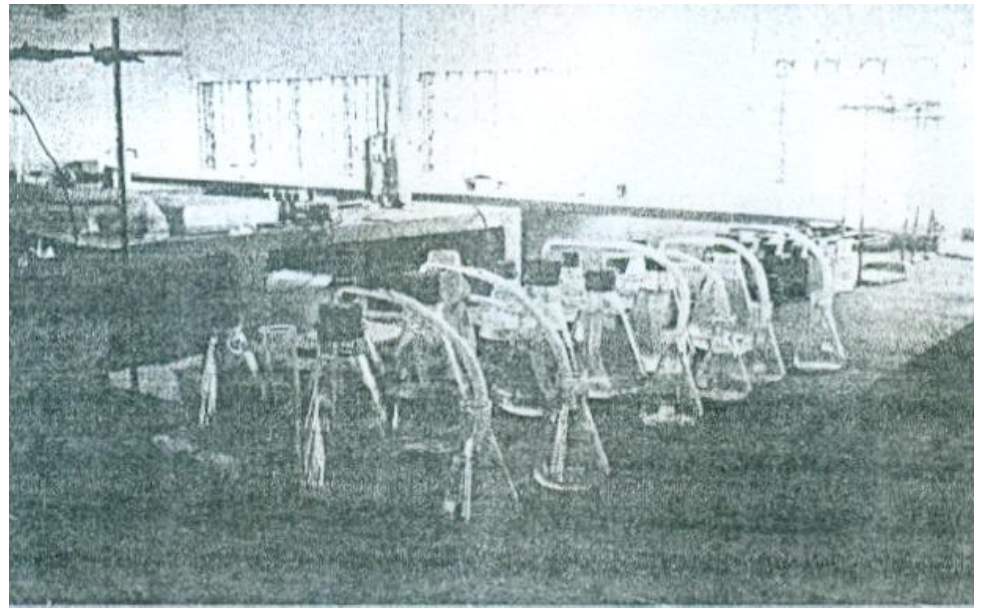

Fig. 3: Digester Set-up

\section{Preparation of Brine Solution}

$1000 \mathrm{ml}$ of water was diluted with sodium chloride until the solution became supersaturated. This forms the stock solution from which portion arc filled into the six Buckner flasks as shown in fig. 3

Biogas production moves from the digester into the Buckner flask obtaining brine where pressure is exerted that causes water to rise in the connecting pipe into the conical flask. The amount or water displaced is measured intermittently using a measuring cylinder which is proportional to the biogas production. And it is known as water displacement method.

\section{Model derivation}

The mixture models are most times referred to as Scheffe's Models. The Scheffe's Model for 2"'1 degree polynomial is as follows: Assuming our mixture models are possesses curvature in the system then a polynomial of higher degree such as given below must be used.

$E(y)=\beta_{o}+\sum_{i=1}^{p} \quad \beta_{i} x_{i}+\sum \quad \sum_{i<j}^{p} \beta_{i j} x_{j}+\cdots+\epsilon$

I.e Equation of independent variable for $2^{\text {nd }}$ degree polynomial 
Where,

$\mathrm{E}(\mathrm{y})=\mathrm{F}_{\mathrm{f}}=\mathrm{f}$ (Plantain Peels, Poultry waste and Water),

Let lateritic soil variable be $\mathrm{x}_{1}$, cement variable be $\mathrm{x}_{2}$, Termite Clay Powder variable be $\mathrm{x}_{3}$, Number of component of the mixture, $\mathrm{p}=3$

$E(y) \Rightarrow F_{f}=\mathrm{f}\left(x_{1}, x_{2}, x_{3}\right)$

Expanding Equation 3.1, we have the general equation as:

$\Rightarrow F_{f}=\beta_{0}+\beta_{1} x_{1}+\beta_{2} x_{2}+\beta_{3} x_{3}+\beta_{12} x_{1} x_{2}+\beta_{13} x_{1} x_{3}+\beta_{23} x_{2} x_{3}+\beta_{11} x_{1}^{2}+\beta_{22} x_{2}^{2}+\beta_{33} x_{3}^{2}-$

The constrain of Scheffe's equation for mixture is that $x_{1}+x_{2}+\ldots x_{p}=1$

$\Rightarrow x_{1}+x_{2}+x_{3}=1$

Thus, let $\beta_{0}=\beta_{0} .1=\beta_{0}\left(x_{1}+x_{2}+x_{3}\right)$

Also, it can be seen that, $x_{2}^{2}=x_{1} x_{1}$ but, $x_{1}=1-x_{2-} x_{3}$

$\Rightarrow x_{1}^{2}=x_{1} \cdot\left(1-x_{2}-x_{3}\right)=x_{1-} x_{1} x_{2}-x_{1} x_{3}$

Similarly,

$x_{2}^{2}=x_{2}-x_{1} x_{2}-x_{2} x_{3}$

$x_{3}^{2}=x_{3}-x_{1} x_{3}-x_{2} x_{3}$

Putting these expression into the general response expression,

$\Rightarrow F_{f}=\beta_{0}\left(x_{1}+x_{2}+x_{3}\right)+\beta_{1} x_{1}+\beta_{2} x_{2}+\beta_{3} x_{3}+\beta_{12} x_{1} x_{2}+\beta_{13} x_{1} x_{3}+\beta_{23} x_{2} x_{3}+\beta_{11}\left(x_{1-} x_{1} x_{2}-x_{1} x_{3}\right)$

$+\beta_{22}\left(x_{2}-x_{1} x_{2}-x_{2} x_{3}\right)+\beta_{33}\left(x_{3}-x_{1} x_{3}-x_{2} x_{3}\right)$

$=\left(\beta_{0}+\beta_{1}+\beta_{11}\right) x_{1}+\left(\beta_{0}+\beta_{2}+\beta_{22}\right) x_{2}+\left(\beta_{0}+\beta_{3}+\beta_{33}\right) x_{3}+\left(\beta_{12}-\beta_{11}-\beta_{22}\right) x_{1} x_{2}+\left(\beta_{13}-\beta_{11}-\right.$ $\left.\beta_{33}\right) x_{1} x_{3}+\left(\beta_{23}-\beta_{22}-\beta_{33}\right) x_{2} x_{3}$

Let

$\left(\beta_{0}+\beta_{1}+\beta_{11}\right)=\mu_{1} ;\left(\beta_{0}+\beta_{2}+\beta_{22}\right)=\mu_{2} ;\left(\beta_{0}+\beta_{3}+\beta_{33}\right)=\mu_{3} ;$

$\left(\beta_{12}-\beta_{11}-\beta_{22}\right)=\mu_{12} ;\left(\beta_{13}-\beta_{11}-\beta_{33}\right)=\mu_{13} ;\left(\beta_{23}-\beta_{22}-\beta_{33}\right)=\mu_{23} ;$

$\Rightarrow F_{f}=\mu_{1} x_{1}+\mu_{2} x_{2}+\mu_{3} x_{3}+\mu_{12} x_{1} x_{2}+\mu_{13} x_{1} x_{3}+\mu_{23} x_{2} x_{3}$

This can be put in compact form as:

$\Rightarrow F_{f}=\sum \quad \sum_{1<i<j<p}^{p} \mu_{i j} x_{i} x_{j}$

Equation 3.4 is the same as equation 3.5. They are called $2^{\text {nd }}$ Scheffe's for three variable -response.

\section{Least Squares Estimation of the Model Parameters}

This procedure is referred to as model fitting. The method of least square chooses the coefficients $\mu_{i}$ and $\mu_{i j}$ in Equation 3.5 so that the sum of the squares of the errors between the experimental expected response $\left(F_{f i}\right.$ and $\left.F_{f i j}\right)$ and predicted expected response $\left(F_{f i}\right.$ and $\left.F_{f i j}\right)$ is minimized.

The least square function is expressed as:

$L=\left[F_{f}-\sum_{1<i<p}^{p} \mu x_{i}+\sum \sum_{1<i<j<p}^{p} \mu_{i j} x_{i} x_{j}\right]^{2}$

The function $\mathrm{L}$ is to be minimized with respect to $\mu_{i}(i=1-3)$ and $\mu_{i j}(1 \leq i \leq j)$

The least square estimator must satisfy

$\frac{\boldsymbol{d} \boldsymbol{L}}{\boldsymbol{d} \mu_{i j}} \mid=-2 \sum_{\mathrm{i}-1}^{\mathrm{n}}\left\lfloor\mathrm{F}_{\mathrm{fi}}-\sum_{1<i<p}^{\mathrm{p}} \mu_{\mathrm{i}} x_{i}+\sum \sum_{1<i<j<p}^{p} \mu_{i j} x_{i} x_{j}\right\rfloor=\mathbf{0}$

And $(i=1-3)$

$\left.\left.\frac{\boldsymbol{d} \boldsymbol{L}}{\boldsymbol{d} \mu_{i j}}\right|_{(1<i<j<p)}=-2 \sum_{\mathrm{i}-1}^{\mathrm{n}} \mid \mathrm{F}_{\mathrm{fi}}-\sum_{1<i<p}^{\mathrm{p}} \mu_{\mathrm{i}} x_{i}+\sum \sum_{1<i<j<p}^{p} \mu_{i j} x_{i} x_{j}\right] x_{i} x_{j}=\mathbf{0}$

Equation 1.5 and 1.6 would result to a system of homogenous equations, which solved would give the values of the unknowns: $\mu_{i}$ and $\mu_{i j}$ of equation 1.3. This procedure is very adaptable to a degree of polynomials.

\section{Procedure for Optimization using Scheffe's Models}

A set of five batch reactors were used as digesters. Each Digester contained fixed amount of water and increasing ratio of plantain peels and poultry waste. These digesters were labeled A, B, C, D, and E, respectively.

This digester acted as the control. The compositions of batch reactor digester arc as follows.

- Digester - A, consisted of I $0.52 \mathrm{~g}$ of plantain peels, $0 \mathrm{~g}$ of poultry waste and $100 \mathrm{mi}$ of water.

- Digester- B consisted or $2.63 \mathrm{~g}$ of plantain peels, $7.89 \mathrm{~g}$ of poultry waste and $100 \mathrm{mi}$ of water.

- Digester- C consisted of $5.26 \mathrm{~g}$ or plantain peels, 5.26 or poultry waste and $100 \mathrm{ml}$ of water (i.e equal amount of waste content).

- Digester - D consisted of $7.89 \mathrm{~g}$ of plantain peels, $2.63 \mathrm{~g}$ of poultry waste and $100 \mathrm{mi}$ of water. 
Predicting the Suitability of Biogas Optimization from the Co-digestion of Plantain Peels and ..

- Digester - E consisted of Og or plantain peels, $10.52 \mathrm{~g}$ of poultry waste and $100 \mathrm{mi}$ of water the vice visa of digester $\mathrm{A}$.

The waste used is poultry waste and plantain peels gotten from farm for the purpose a [this experiment"

\section{X. pH Determination}

A digital $\mathrm{pH}$ meter with glass reference electrode was used for all $\mathrm{pH}$ measurement. The meter was set with distilled water and adjusted at room temperature before measurement was taken.

\section{Volatile Organic Matter and Ash Content Analysis}

A portion of poultry waste and plantain Peels previously dried was grained and weighed. The samples were sent to the lab to determine the volatile organic matter. 1 he dry sample was transferred into a muffle furnace and ignited at 550 degree Celsius for two hours. The loss in weight was calculated and is as shown in Table C1- C3.

\section{Results and Discussion}

The result for the cumulative biogas production and optimum mix ratio corresponding to maximum biogas yield are discussed below.

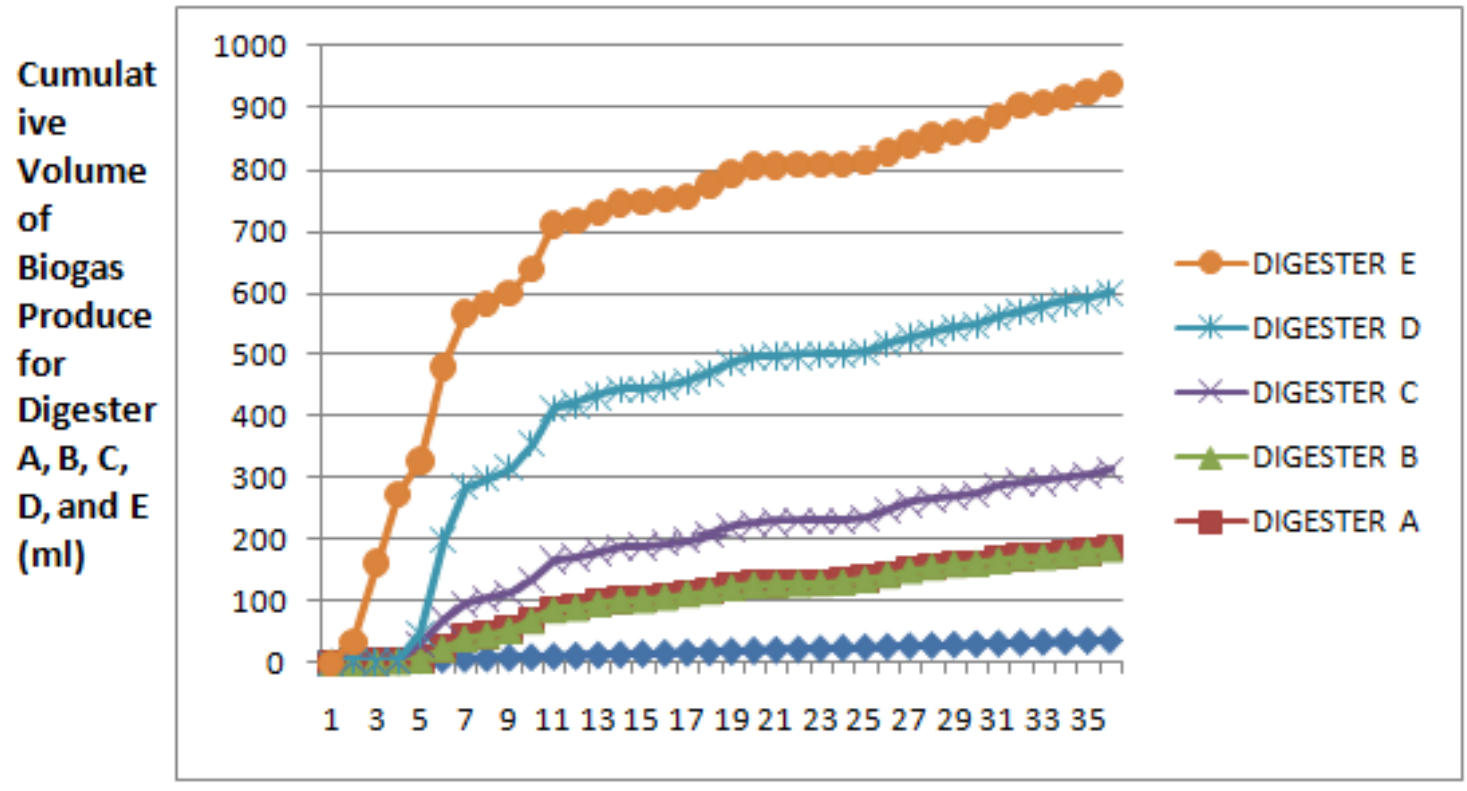

\section{Retention Time (days)}

Fig. 4: Cumulative Volume of Biogas Against Time

The cumulative biogas produced for digester A, B, C; D and E were observed to be $148.9 \mathrm{ml}, 0 \mathrm{ml}$, $129 \mathrm{ml}, 287.4 \mathrm{ml}$ and $336.1 \mathrm{ml}$ respectively. In- addition, digester $\mathrm{E}$ which has a ratio or 0: I produced 336.11111 which is the maximum yield with retention time or 35 days; this is due to the presence or bacteria population from the poultry waste. Digester D, A and C was the next to produce a maximum yield of $287.4 \mathrm{ml}, 148.9 \mathrm{ml}$ and $129 \mathrm{ml}$ respectively. This can be attributed to the $\mathrm{C}: \mathrm{N}$ ratio, he fact that the poultry waste has undergone initial digestion in the animals stomach.

\section{Designing At Maximum Conversion Efficiency}

Table 4.2 shows the design parameter assumption for an anaerobic digester.

The geometrical dimension of a cylindrical shaped biogas digester is shown in the Appendix. 
Predicting the Suitability of Biogas Optimization from the Co-digestion of Plantain Peels and ..

Table 4.2 Design parameter Assumption

\begin{tabular}{|l|l|}
\hline For Volume & For Geometrical Dimension \\
\hline $\mathrm{V}_{\mathrm{C}} 5 \% \mathrm{~V}$ & $\mathrm{D}=1.3078 \mathrm{~V}^{1 / 3}$ \\
$\mathrm{VS} 15 \% \mathrm{~V}$ & $\mathrm{~V}_{1}=0.0827 \mathrm{D}^{2}$ \\
$\mathrm{~V}_{\mathrm{gs}}+\mathrm{V}_{\mathrm{f}}=80 \% \mathrm{~V}=\mathrm{Q} * \mathrm{HRT}$ & $\mathrm{V}_{2}=0.05011 \mathrm{D}^{3}, \mathrm{~V}_{3}=0.3142 \mathrm{D}^{3}$ \\
$\mathrm{~V}_{\mathrm{gs}}=0.5\left(\mathrm{~V}_{\mathrm{gs}}+\mathrm{V}_{\mathrm{f}}+\mathrm{V}_{\mathrm{s}} \mathrm{k}\right.$ & $\mathrm{R}_{\mathrm{l}}=0.725 \mathrm{D}$ \\
Where K= Gas production rate & $\mathrm{R}_{2}=1.0625 \mathrm{D}$ \\
per $\mathrm{m}^{3}$ digester volume per & $\mathrm{F}_{1}=\mathrm{D} / 5$ \\
day & $\mathrm{F}_{2}=\mathrm{D} / 8$ \\
& \\
\hline
\end{tabular}

$\mathrm{V}_{1}=$ Volume of gas collecting chamber

$\mathrm{V}_{2}=$ VoluI11c of gas chamber

$\mathrm{V}_{\mathrm{f}}=$ Volume of fermentation area

$\mathrm{V}_{\mathrm{S}}=\mathrm{VOIUIllC}$ of sludge arox

$\mathrm{D}=$ diameter

$\mathrm{R}_{\mathrm{i}}=$ surface radius (top

$\mathrm{R}_{2}=$ surface radius (bottom

$\mathrm{V} \quad=$ Total volume

\section{Design Parameter}

- Selected of materials

- Total solid contain contains calculation of organic material is usually used as the material unit to indicate the biogas producing rate of the material Most favorable total solid value desired is $4.04 \%$

- Favorable temperature, $\mathrm{C}: \mathrm{N}$ ratio for good fermentation.

Temperature: Mesophilic: $20^{\circ} \mathrm{C}-35^{\circ} \mathrm{C}$

$\mathrm{C}: \mathrm{N}$ ratio range from 20: 1 to $30: 1$

Hydraulic retention time HRT

For mesophilic digestion where temperature varies from $200 \mathrm{C}$ to $350 \mathrm{C}$ and HRT is greater than 35days.

In designing the batch digester to operate at maximum conversion fficiency

of substrate, the result obtained from figure 4.5.

These figures show that an optimum poultry-waste concentration of $93.7 \%$ of the total solid concentration produced maximum conversion efficiency of substrate. These values are equal to $10.52 \mathrm{~g}$ of poutry waste and og of plantain peels in $250 \mathrm{ml}$ of water. Thus, the given values can be used as input data and digester dimensions arc as 10110ws:

Working volume of digester $=\mathrm{Vgs}+\mathrm{vf}=\mathrm{Qx}$ HRT

$\mathrm{Q}=$ loading rate $=4.04 \mathrm{TS}=4.04 \mathrm{in} 100 \mathrm{~kg}$ influent

Thus Ikg TS=I 0014. 04g of Influent

There, $10.52 \mathrm{~g}$ TS $=1$ O. $5214.04 \times 10.52 \mathrm{Iday}=27.40 \mathrm{~kg} / \mathrm{day}$

Taking HRT as 35 day

Since $1000 \mathrm{~kg}$ of water $1 \mathrm{~m}^{3}$

$\mathrm{Vgs}+\mathrm{Vf}=0.9$

$9.58=0.9 \mathrm{~V}$ 
$\mathrm{V}=10.81 \mathrm{~m}^{3}$

Hence, $\mathrm{Vgs}+\mathrm{Vf}=27.40 \times 35=958.77$

$\mathrm{D}=1.3078 \mathrm{~V}^{1 / 3}$

$=2.89$

From geometric assumptions,

$\mathrm{V}_{3}=0.3142 \mathrm{D}^{3}$

$=3.14 \times \mathrm{D}^{2} \times \mathrm{H} / 4$

$\mathrm{H}=1.16$

Also,

$\mathrm{RI}=0.725 \mathrm{D}=2.10 \mathrm{~m}$

$\mathrm{R} 2=\mathrm{I} .0625 \mathrm{D}=3.07 \mathrm{~m}$

$\mathrm{F} 1=\mathrm{D} / 5$

$\mathrm{F} 2=\mathrm{D} / 8$

$\mathrm{VI}=0.0827 \mathrm{D}^{3}=2.00 \mathrm{~m}$

$\mathrm{V} 2=0.05011 \mathrm{D}^{3}$

$\mathrm{V} 3=0.3142 \mathrm{D}^{3}$

$\mathrm{Vc}=0.05 \mathrm{~V}=0.54 \mathrm{~m}^{3}$

$\mathrm{V}=\mathrm{V}_{\mathrm{c}}+\mathrm{V} 1+\mathrm{V}_{3}=0.54+2.00+1.21+7.58=11.33 \mathrm{~m}^{3}$

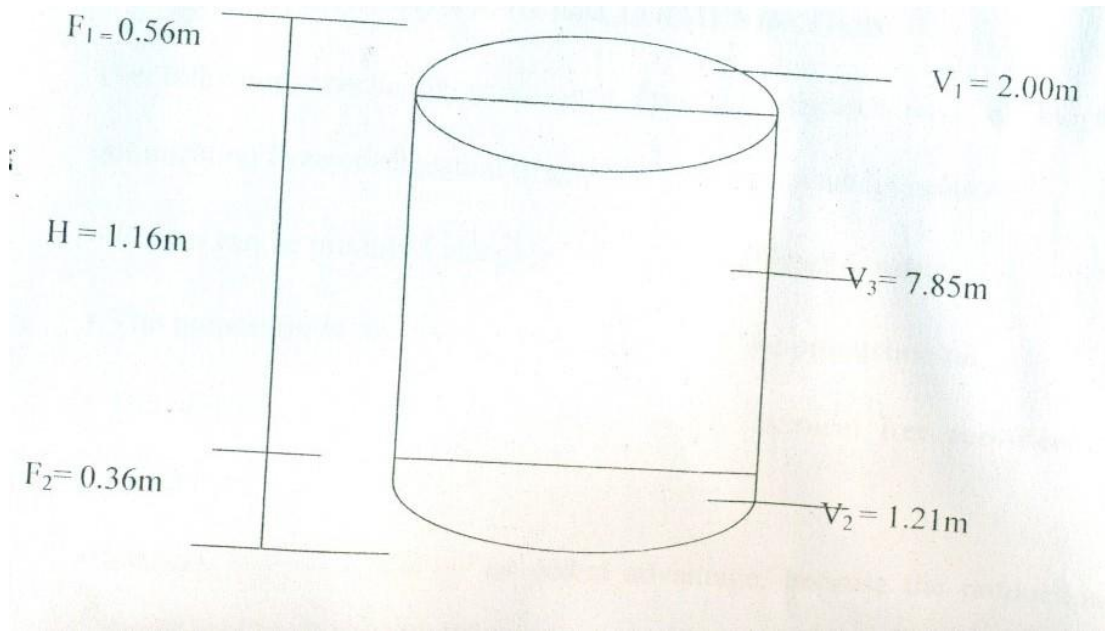

Table C1: Mixed proportion of Waste Materials

\begin{tabular}{|l|l|l|l|l|}
\hline DIGESTER & $\begin{array}{l}\text { PANTAIN } \\
\text { PEELS }\end{array}$ & $\begin{array}{l}\text { POULTRY } \\
\text { WASTE }\end{array}$ & $\begin{array}{l}\text { PP/PW PERCENTAGE } \\
\text { CONCENTRATION }\end{array}$ & $\begin{array}{l}\text { CARBON NITROGEN (C:N) } \\
\text { RATIO }\end{array}$ \\
\hline A & 10.52 & 0 & $100: 0$ & $41: 1.78$ \\
\hline B & 2.63 & 7.89 & $20: 80$ & $49.5: 2.5$ \\
\hline C & 5.26 & 5.26 & $50: 50$ & $49.5: 2.31$ \\
\hline D & 7.89 & 2.63 & $80: 20$ & $42.7: 9.53$ \\
\hline E & 0 & 10.52 & $0: 100$ & $52.1: 2.71$ \\
\hline
\end{tabular}

Table C2: Percentage (\%) of Volatile matter

\begin{tabular}{|l|l|l|l|l|}
\hline No. of digester & $\begin{array}{l}\text { Empty wt of } \\
\text { crucible }\end{array}$ & $\begin{array}{l}\text { Crucible wt of } \\
\text { VOM +1g }\end{array}$ & After Ashing & $\begin{array}{l}\text { Percentage } \\
(\%) \text { VOM }\end{array}$ \\
\hline A & 23.745 & 24.745 & 24.007 & 73.80 \\
\hline B & 26.561 & 26.561 & 26.662 & 89.90 \\
\hline C & 26.304 & 25.413 & 89.10 \\
\hline D & 25.304 & 26.564 & 25.795 & 76.90 \\
\hline E & 25.564 & 25.758 & 24.821 & 93.70 \\
\hline
\end{tabular}

Table C3: Percentage (\%) of Volatile matter

\begin{tabular}{|l|l|l|l|l|}
\hline No. of digester & $\begin{array}{l}\text { Empty wt of } \\
\text { crucible }\end{array}$ & $\begin{array}{l}\text { Crucible wt of } \\
\text { VOM +1g }\end{array}$ & After Ashing & $\begin{array}{l}\text { Percentage } \\
(\%) \text { Ash }\end{array}$ \\
\hline A & 14.945 & 15.945 & 14.007 & 26.20 \\
\hline B & 29.561 & 30.561 & 29.662 & 10.10 \\
\hline C & 36.907 & 35.513 & 10.90 \\
\hline D & 35.907 & 28.164 & 27.395 & 23.10 \\
\hline E & 27.164 & 36.858 & 35.921 & 6.30 \\
\hline
\end{tabular}


Predicting the Suitability of Biogas Optimization from the Co-digestion of Plantain Peels and ..

Table C4: Selected variables for Digester A

\begin{tabular}{|l|l|l|l|l|l|l|l|l|}
\hline \multicolumn{1}{|c|}{$S N$} & \multicolumn{1}{|c|}{$x_{1}$} & \multicolumn{1}{|c|}{$x_{2}$} & \multicolumn{1}{|c|}{$x_{1} x_{2}$} & \multicolumn{1}{c|}{$x_{1}^{2}$} & \multicolumn{1}{c|}{$x_{2}^{2}$} & \multicolumn{1}{|c|}{$x_{1}^{2} x_{2}$} & \multicolumn{1}{|c|}{$x_{1} x_{2}^{2}$} & \multicolumn{1}{c|}{$x_{1}^{2} x_{2}^{2}$} \\
\hline 1 & 2.00 & 0.00 & 0.00 & 4.00 & 0.00 & 0.00 & 0.00 & 0.00 \\
\hline 2 & 4.00 & 1.40 & 5.60 & 16.00 & 1.96 & 22.40 & 7.84 & 31.36 \\
\hline 3 & 6.00 & 33.40 & 200.40 & 36.00 & 1115.56 & 1202.40 & 6693.36 & 40160.16 \\
\hline 4 & 10.00 & 75.40 & 754.00 & 100.00 & 5685.16 & 7540.00 & 56851.60 & 568516.00 \\
\hline 5 & 14.00 & 87.60 & 1223.40 & 196.00 & 7673.76 & 17169.60 & 107432.64 & 1504057.00 \\
\hline 6 & 18.00 & 103.50 & 1863.00 & 324.00 & 10712.25 & 33534.00 & 192820.50 & 3470769.00 \\
\hline 7 & 22.00 & 107.10 & 2356.20 & 484.00 & 11470.41 & 51836.40 & 252349.02 & 5551678.40 \\
\hline 8 & 26.00 & 123.50 & 3211.00 & 676.00 & 15252.25 & 83486.00 & 396558.50 & 10310521.00 \\
\hline 9 & 30.00 & 135.10 & 4053.00 & 900.00 & 18252.01 & 121590.00 & 547560.30 & 16426809.00 \\
\hline 10 & 34.00 & 144.90 & 4926.60 & 1156.00 & 20996.01 & 167504.40 & 713864.34 & 24271388.00 \\
\hline$\sum$ & 166.00 & 811.90 & 18596.20 & 3892.00 & 91159.37 & 483885.20 & 2274138.10 & 62143929.92 \\
\hline
\end{tabular}

Table C5:Selected variables for Digester A

\begin{tabular}{|l|l|l|l|}
\hline \multicolumn{1}{|c|}{$S N$} & \multicolumn{1}{|c|}{$\sum f_{i} x_{1}$} & \multicolumn{1}{c|}{$\sum f_{i} x_{2}$} & \multicolumn{1}{c|}{$\sum f_{i} x_{1} x_{2}$} \\
\hline 1 & 0.00 & 0.00 & 0.00 \\
\hline 2 & 5.60 & 1.96 & 7.84 \\
\hline 3 & 200.40 & 1115.56 & 6693.36 \\
\hline 4 & 754.00 & 5685.16 & 56851.60 \\
\hline 5 & 9.80 & 61.32 & 858.48 \\
\hline 6 & 300.60 & 1728.45 & 31112.10 \\
\hline 7 & 829.40 & 4037.67 & 88828.74 \\
\hline 8 & 452.40 & 2148.90 & 55871.40 \\
\hline 9 & 1632.00 & 7349.44 & 220483.20 \\
\hline 10 & 1849.60 & 7882.56 & 268007.04 \\
\hline$\sum$ & 6033.80 & 30011.02 & 728713.76 \\
\hline
\end{tabular}

The homogenous set of equations resulting from equation 1.5 and 1.6 are as follows:
? ${ }_{1} \sum x_{1}^{2}+?_{2} \sum x_{1} x_{2}+?_{12} \sum x_{1}^{2} x_{2}=\sum f_{i} x_{1}$
$-1.7$
目 ${ }_{1} \sum x_{1} x_{2}+$ ? $_{2} \sum x_{2}^{2}+?_{12} \sum x_{1} x_{2}^{2}=\sum f_{i} x_{2}$
$-1.8$
? ? $_{1} \sum x_{1}^{2} x_{2}+?_{2} \sum x_{1} x_{2}^{2}+?_{12} \sum x_{1}^{2} x_{2}^{2}=\sum f_{i} x_{1} x_{2}$
$-1.9$

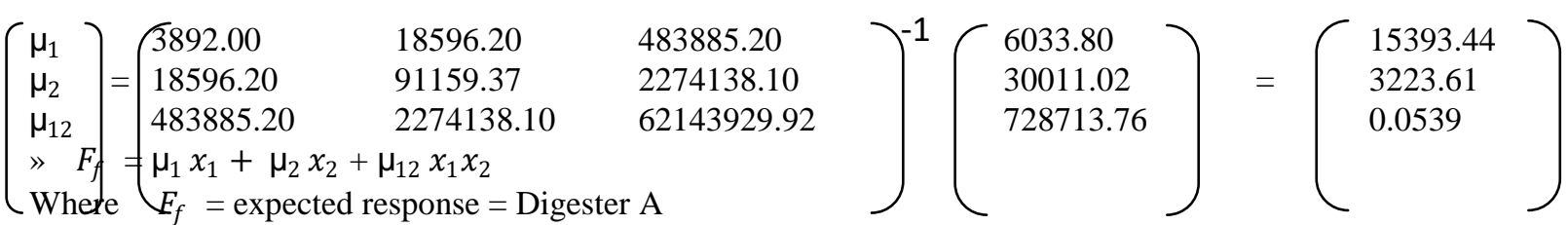

and $x_{1}$ and $x_{2}=$ readings obtained from the cumulative biogas with respect to time.

Fig. 5: Digester A

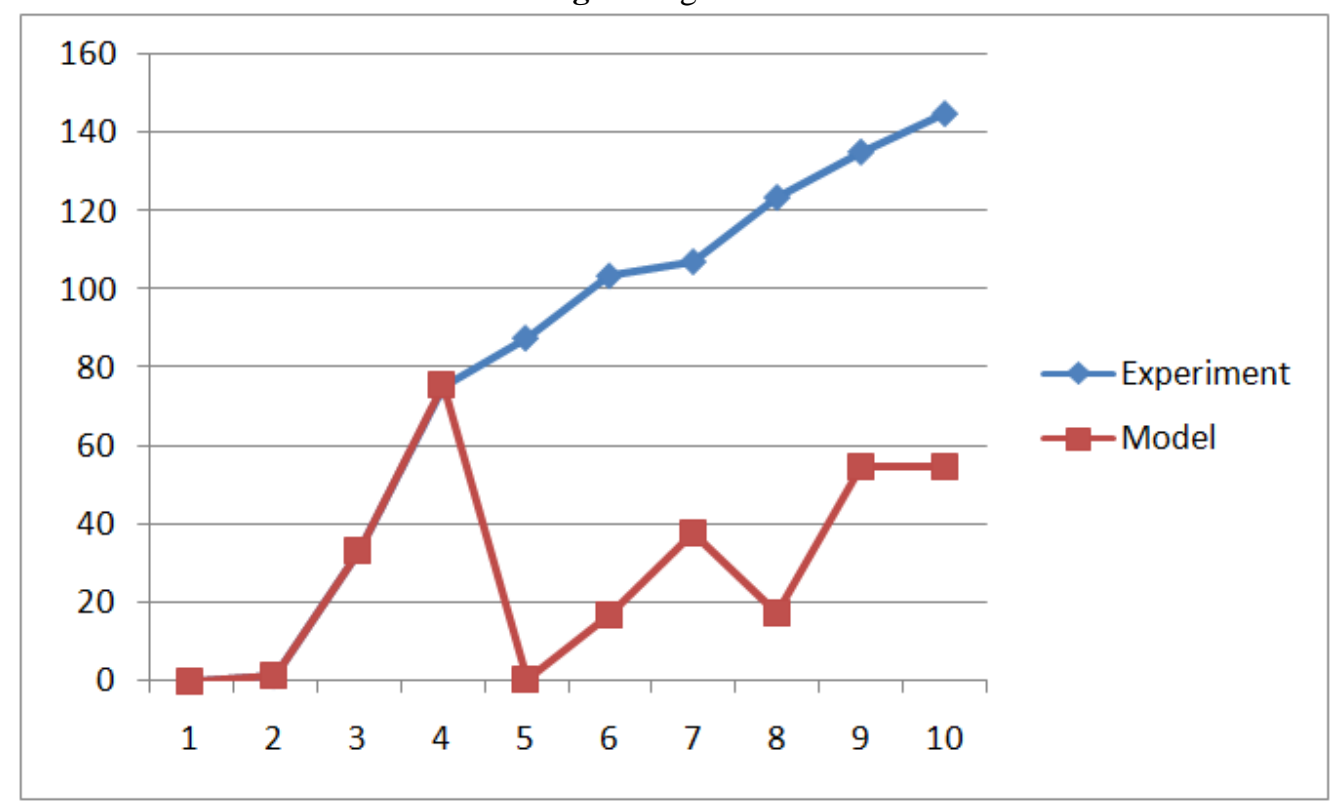


Fig. 6: Digester C

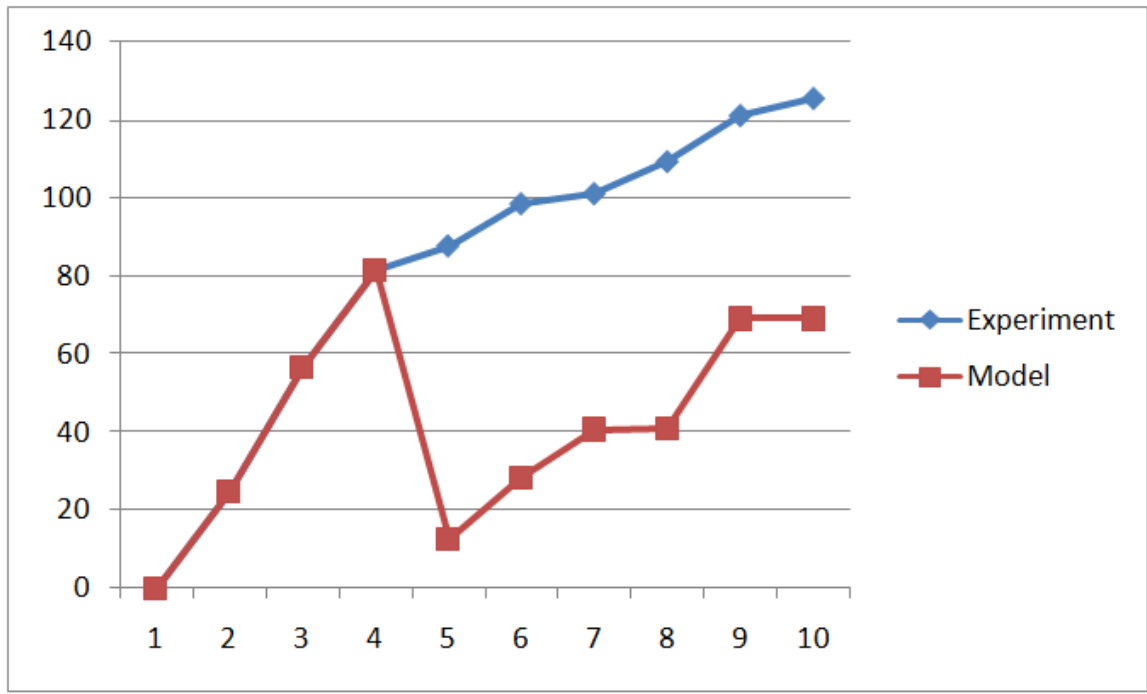

Fig. 7: Digester D

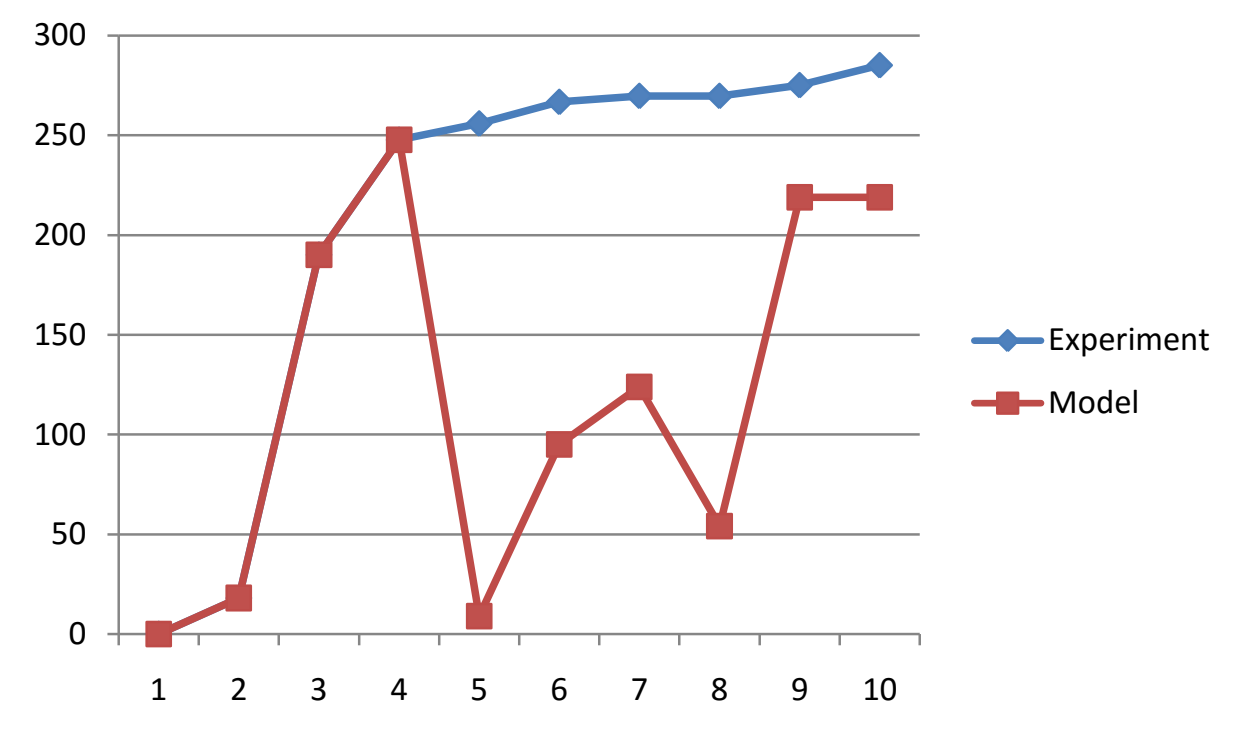

Fig. 8: Digester E

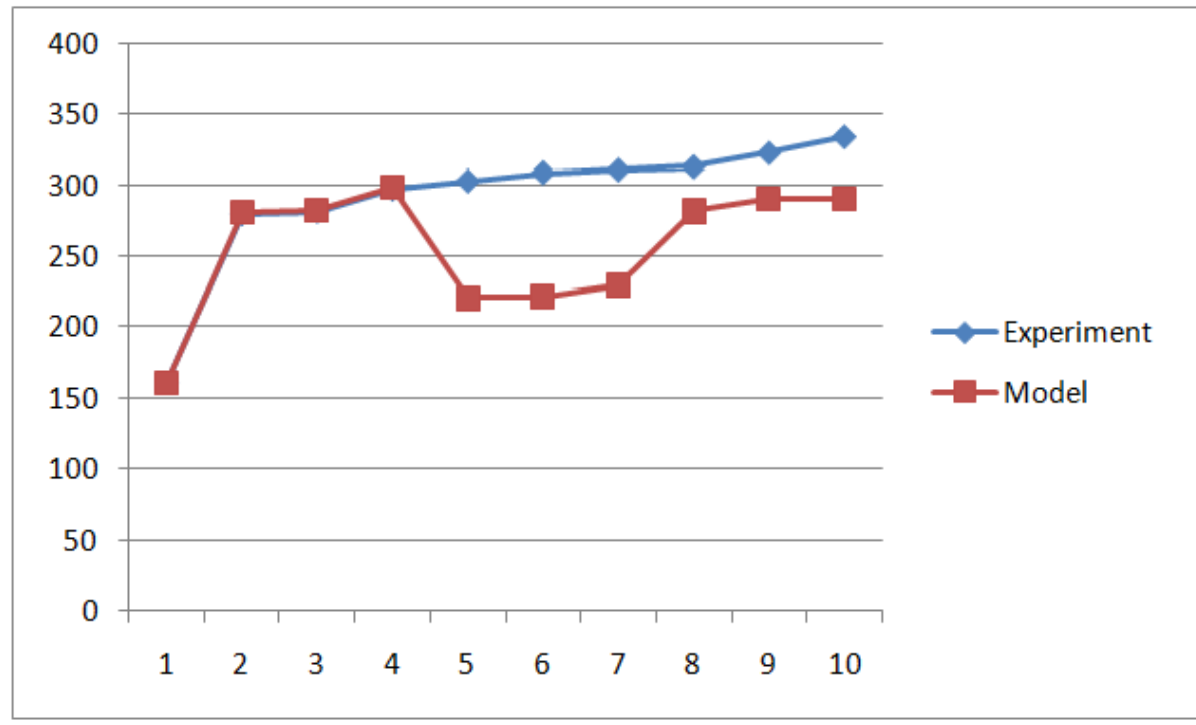




\section{Modeling of Strength Indices and Model Verification}

Scheffe's predictive mixture models.Scheffe, H. (1958 and 1963) were formulated for Digester A, C, D and E. The correlation between the experimented and the model results were computed for $r= \pm$ and the $t$ - test was used to verify the significance of $r$ at 5\% level. This was done to facilitate the application of laboratory results and serve as a guide in predicting relationship between variables and also reduce the rigorous laboratory work by facilitating prediction of results. Figure (5 to 8$)$ shows the plots of the experimental and predicting models from equations $(1.7-1.9)$ developed. The models were those for Digester A, C, D, and E. Digester B yield no gas as a result of the mixture content.

Digester A $=-0.5929 x_{1}+0.4876 x_{2}-0.0015 x_{1} x_{2}$

Digester $\mathrm{C}=2.2869 x_{1}+0.0418 x_{2}-0.0030 x_{1} x_{2}$

Digester $\mathrm{D}=0.0501 x_{1}+0.5560 x_{2}-0.0004 x_{1} x_{2}$

Digester $\mathrm{E}=-28.63 x_{1}+1.0723 x_{2}+0.0803 x_{1} x_{2}$

\section{Conclusion}

Models developed correspond with experimental result to a reasonable degree of accuracy and could be successfully used to predict the biogas optimization in the absence of experimental data from the co-digestion of plantain peels and poultry waste.

\section{Acknowledgement}

The Author acknowledged the Almighty God for wisdom, knowledge and understanding. Also acknowledge Engr. Yusuf Mormoh.

\section{References}

[1]. Aruh, Band Baul, B.S.(1986) Textbook or organic chemistry, McGraw Hill Tokyo, 8, 28-32.

[2]. Burkey, D.A. (2000)." Nothing Wasted". Civil Engineering. 4,62-64.

[3]. Gerald, K. (1998) Environmental Engineering, McGraw-Hill, New York. 3, 34-39.

[4]. Ghorsh, S. (1987). "Improved Sludge Gasification by Two -phase Anaerobic Digestion" Journal of Environmental Engineering 113(6), 1265-1284

[5]. Hobson, P. and Taiganides, E. P. (1983). "Anaerobic Digestion of Cellulose-Diary Cattle Manure Mixture".Agricultural Wastes. 8, $105-118$

[6]. Mathew, J.c. (1997); Calculation in Mordern Chemistry, Hutchinson Publishers, London, 3, 9 - 11.

[7]. Marchaim, U. (1992); Biogas field book, Sahayogi press, k au imay, Nepal. 8, 98-101.

[8]. Singh, R.I3. (1974); "Biogas Plant Generating Methane From animal Dung". 14, 123-150.

[9]. Scheffe, H. (1958); "Experiments with Mixtures," Journal of Royal Statistical Society, Series B. 20, pp. 344-360

[10]. Scheffe, H. (1963); "The Simplex-centroid Design for Experiments with Mixtures," Journal of Royal Statistical Society, Series B. 25 , pp. $235-251$. 